Review

Goran Bakalar, Ph.D.

E-mail: Goran.Bakalar@xnet.hr

MH Systems Inc., San Diego, USA

International Maritime Technology Consultancy, Put Radosevca 52, 21000 Split, Croatia Vinko Tomas, Ph.D.

\title{
Possibility of Using Flow Cytometry in the Treated Ballast Water Quality Detection
}

\begin{abstract}
In this article, monitoring of ballast water after its treatment by any of BWTS (Ballast Water Treatment System) on board ships has been analyzed. The efficiency of those systems has shown to be the major problem as there are no systems for tracking ship ballast operations. The overall aim of the study was to emphasize the necessity of monitoring the ballast water treatment on board ships and to propose a solution. The flow cytometry technology and applications of flow cytometers have been analyzed as well. The functionality and possibility of using this technology for detection of the treated ballast water quality has been explained. The results of the flow cytometry detection have been confirmed mathematically. The possibility of finding the remaining microorganisms in the treated ballast water has been calculated and the result was a very high percentage of $82 \%$. The study presented in this paper aids in the understanding of how important it is for results of the ballast water treatment systems operation to be monitored since such monitoring is also in the interest of protecting the environment.
\end{abstract}

Key words: ballast water, treating methods, detection, flow cytometry

\section{Introduction}

The problem analyzed in this article is the inconsistent operation of automated ballast water treatment systems on board ships that could cause contamination of domestic waters. The environment could be affected by harmful algae, bacteria or any other substances dangerous for humans or the environment. Ballast water treatment presents a technological challenge to the current state-of-the-art technologies because of the unique chemical and physical characteristics of the ballast water, and the large number and diversity of organisms [2]. 
The International Convention for the Control and Management of Ships Ballast Water \& Sediments was adopted by consensus at a Diplomatic Conference at IMO in London on Friday, 13 February 2004 [20]. Regulations and standards established by the IMO (International Maritime Organization) require treatment limits to be met independently and call for vessel self monitoring [1]. Ballast water will have to be treated once this convention comes into effect [12]. The Convention requires certified inspectors to make their reasonable efforts to avoid any unnecessary ship layoff due to the potentially required sampling. That means that the advantage is usually given to the party of transportation instead of the sea protection. Inspectors could order a designated institution or certified laboratory to take samples and to analyze ballast water that any crew intents to discharge into the sea. Laboratory analyses need to find specific microorganisms in the ballast water and to determine salinity in order to find the origin of the ballast water [5]. If the result of laboratory analyses doesn't detect dangerous microorganisms or any other reason that would prevent the ballast water discharge, all the expenses would be paid by the Ministry that the inspector represents. There comes the need for cheaper and faster inspections. New technologies could help to find better ways for that. The experience has shown problems concerning repairs taking place on board ships [4][7]. The repair of heating coils existing in cargo tanks (one of the ways to keep the liquid cargo temperature) would be much harder if happened in ballast water tanks. The basic difference is in the height of the tanks: cargo tanks are three to ten meters high and ballast tanks range between a half meter and up to 1.5 meters on most ships. It is extremely hard to do any repair or welding job that high. So, most of those problems, when they happen, are usually postponed onboard wherever possible and crew members keep that status until the first opportunity arises for repair ashore.

Any problem could happen in connection with any possible repair of the ballast water treating device or welded holders of that device. Any equipment existing in the salt water is in constant exposure to damages. Ship's movements in storms combined with the exposure to salt bring up a very big risk from damages or improper functioning of any device, heating coils or parts of other methods of ballast water treatment in ballast water tanks. Oil is the usually used liquid to bring the required temperature into heating coils. Should the ballast inspector find any contamination by oil, it would be impossible in a system of neutralization by heat to locate exactly the point where the oil from heating coils leaks. Even if the hole were found, there are measures and the law that require how and where it is allowed for that kind of damage to be repaired.

Other systems could be affected by clogged filters (UV ballast water management systems), improper functioning of the de-chlorination unit (chlorination ballast water management system), in addition to many other possibilities.

Another very high risk could be encountered where, due to loyalty to their company, crew members would use a broken ballast water management system without reporting it. One of the solutions to control the validity is to give the opportunity to new detection technologies. This paper reviews a methodology that was a part of the study and research done for author's doctoral thesis. 


\section{Detection methodology}

The detection of algae and other bio invasive organisms in the ballast water is an important issue. It is necessary to avoid expenses that could happen by inaccurate inspectors' decisions and there is also the obligation to protect the nature. Crews and ship owners take the responsibility of the ballast water treatment on board their ships. The experience of using monitoring devices (even if not fixed in the salt water), like the oil discharge monitor, has brought about many a different overwork for crew members. The most popular one is to by-pass the oil discharge monitor in the monitoring system on board ships. Crew members all over the world are expected to invent other ways to by-pass the improper operation of devices, in this case of the ballast water treatment device. A good method to detect unwanted microorganisms needs to be dynamic and to enable extremely fast scanning. It also needs to format data, analyze and process large data files.

The deoxyribonucleic acid (DNA) analysis has opened a new way to the science to answer old questions: the structure of DNA has taught researchers a fundamental lesson and the secret of how genetic information is stored, transferred, and copied [13]. The DNA analysis method was one of initiation to flow cytometry analysis. DNA analyses are done in laboratory and sometimes days are needed to inspect some objects of detection. The DNA taxonomy is based on the analysis of small segments of genome. Different organisms round the world contain different DNA. The group of nucleotides of each alga has a different barcode that exists in different algae. Those barcodes filed in a database are used to identify algae. The time of DNA detection has been shortened from days in the past down to three hours [3].

\subsection{The flow cytometry detection methodology}

Flow cytometry is a methodology for determining and quantitating cellular features, organelles or cell structural components primarily by both optical and electronic means. Although it measures one cell at a time and the newest equipment is able to process up to several hundred thousands of cells in a few seconds. Flow cytometry can be used to count and even distinguish cells of different types in a mixture by quantitating their structural features. Therefore, flow cytometry has great advantages compared to traditional microscopy since it permits the analysis of a greater number of cells in a fraction of the time [14].

The flow cytometric analysis principle is that the cells are passing through a laser beam one by one at a high speed and their individual light scattering and fluorescence properties are recorded to form an optical fingerprint for each cell. This separates the flow cytometric method from bulk methods for fluorescence spectra and/or size spectra for bulk volumes of water where it is much harder to discriminate between the contributions of the various groups in the water since the readings are collected for all particles at once. Flow cytometry allows easy recognition of different groups in the 
sample and quantification of their abundance as well as their optical properties (size, pigment) - even the detection of a few rare cells from within a high number of cells from a blooming species. A beam of light of laser of a single wavelength is directed onto a stream of fluid. A number of detectors are aimed at the point where the stream passes through the light beam: one in line with the light beam (Forward Scatter Channel or FSC) and several perpendicular to it (Side Scatter Channel or SSC) and one or more detectors. Each suspended particle from 0.2 to 150 micrometers passing through the beam scatters the ray, and fluorescent chemicals found in the particle or attached to the particle may be excited into emitting light at a longer wavelength than the light source. This combination of lights is picked up by the detectors, and, by analyzing fluctuations in brightness at each detector, it is then possible to derive various types of information about the physical and chemical structure of each individual particle. FSC correlates with the volume of the cells and SSC depends on the inner complexity of the particle [16].

\subsection{Flow cytometers}

Modern flow cytometers are able to analyze several thousand particles every second, in real time, and can actively separate and isolate particles having specified properties. A flow cytometer is similar to regular microscopes, except that, instead of producing an image of the cell, flow cytometry offers the "high-throughput" (for a large number of cells) automated quantification of set parameters. To analyze solid tissue, a single-cell suspension must first be prepared.

A flow cytometer has five main components:

- a flow cell - liquid stream (sheath fluid), which carries and aligns the cells so that they pass single file through the light beam for sensing

- a measuring system - commonly used are the measurement of impedance (or conductivity) and optical systems - lamps; high-power water-cooled lasers; low-power air-cooled lasers, diode lasers (blue, green, red, violet) resulting in light signals

- a detector and the Analogue-to-Digital Conversion (ADC) system - which generates FSC and SSC as well as fluorescence signals from light into electrical signals that can be processed by a computer

- an amplification system

- a computer for analysis of the signals [14].

The process of collecting data from samples using the flow cytometer is termed acquisition. Acquisition is mediated by a computer physically connected to the flow cytometer and the software which handles the digital interface with the cytometer. The software is capable of adjusting parameters (i.e. voltage, compensation, etc.) for the sample being tested, and also assists in displaying the initial sample information while acquiring sample data to insure that parameters are set correctly [17]. 
Early flow cytometers were, in general, experimental devices, but technological advances have enabled widespread applications for use for a variety of both clinical and research purposes. Modern instruments usually have multiple lasers and fluorescence detectors. The current record for a commercial instrument is four lasers and 18 fluorescence detectors [17]. Increasing the number of lasers and detectors allows for multiple antibodies labeling, and can more precisely identify a target population by their markers.

The data generated by flow cytometers can be plotted in a single dimension, or in two-dimensional dot plots or even in three dimensions. The regions on these plots can be sequentially separated, based on fluorescence intensity, by creating a series of subset extractions, termed gates. There exist specific gating protocols for diagnostic and clinical purposes. The plots are often made on logarithmic scales. Because different fluorescent dyes' emission spectra overlap, signals at the detectors have to be compensated electronically as well as computationally. Data accumulated using the flow cytometer can be analyzed using software. Once the data are collected, there is no need to stay connected to the flow cytometer. For this reason, the analysis is most often done on a separate computer. This is especially necessary in core facilities where usage of these machines is in high demand.

\subsubsection{Applications}

The technology has applications in a number of fields, including molecular biology, pathology, immunology, plant biology and marine biology. It has a broad application in medicine (especially in transplantation, hematology, tumor immunology and chemotherapy). In marine biology, the auto-fluorescent properties of photosynthetic plankton can be exploited by flow cytometry in order to characterize abundance and community structure. In protein engineering, flow cytometry is used in conjunction with yeast display and bacterial display to identify cell surface displayed protein variants with desired properties. It is also used to determine ploidy of grass carp fry [16].

Traditional flow cytometers analyze thousands of cells per second acquiring basic total fluorescence and light scattering per cell. This is proportional to particle size and pigment content.

In the cytosense instruments, the signals from all the detectors are not only digitized continuously, they are also stored for each particle. Since the particles flow through the laser focus in a stretched-out manner, these digital profiles are actually length scans of the particle, representing the distribution of its bodyparts along its length axis with regard to their light scattering and fluorescing properties. This fluid driven laser scanning of individual particles is called silico-imaging and uses the normal flow cytometer setup combined with special data grabber boards. The optional curvature sensor adds a two-dimensional component to the silicoimages using a laser beam polarization setup only available on flow cytometers. The advantages of silico-imaging or scanning is the high acquisition rate of up to 1000 scans per second through a USB 
interface, and the suitability of the data format for the standard flow cytometer data analysis and fast processing of large data files. Libraries of these fingerprints allow for automatic classification and enumeration of groups and species from many data sets as well as for online warning for target (algae) species. Since flow cytometers can scan microorganisms as small as $2 \mu \mathrm{m}$, it is possible to use them for ballast water content screening. In this example, illustrated in Figure 1, it is obvious that, as a result of flow cytometer detection, a sample of ballast water contains $80 \%$ of microorganisms $<$ $10 \mu \mathrm{m}$. The BWMC 2004 did not consider microorganisms smaller than $10 \mu \mathrm{m}$ as a treatment aim and they were not limited by D-2 regulation [20]. Even if they are too small for the detection, they could be detected by flow cytometry, as shown in Figure 1.

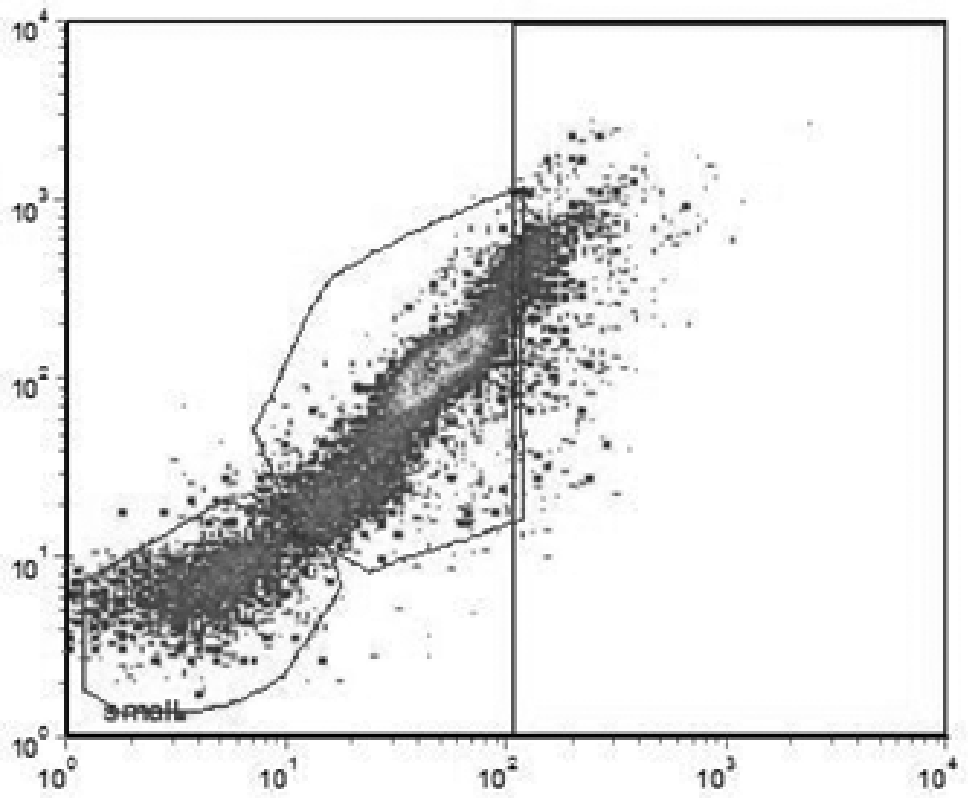

Figure 1 - Scans of flow cytometer technology: 80\% of microorganisms in ballast water result $<10 \mu \mathrm{m}$ [15]

During the experiment in the Great Ships Initiative Institute, Superior, USA, Dr Cangelosi scanned a sample of the water right after and hours after the neutralization. This is a good example of the flow cytometry quality, done in a laboratory that implicates a good possibility for use on ships as well, but it should be in a fully automated way. The following picture (Figure 2) shows the quality of flow cytometry scans done when the microorganisms were still alive and when they were neutralized. At the left side of Figure 2, colored in green, microorganisms are alive. On the right side of the picture, the microorganisms are dead, so the treatment was successful and the flow cytometer detection result was good as well. 


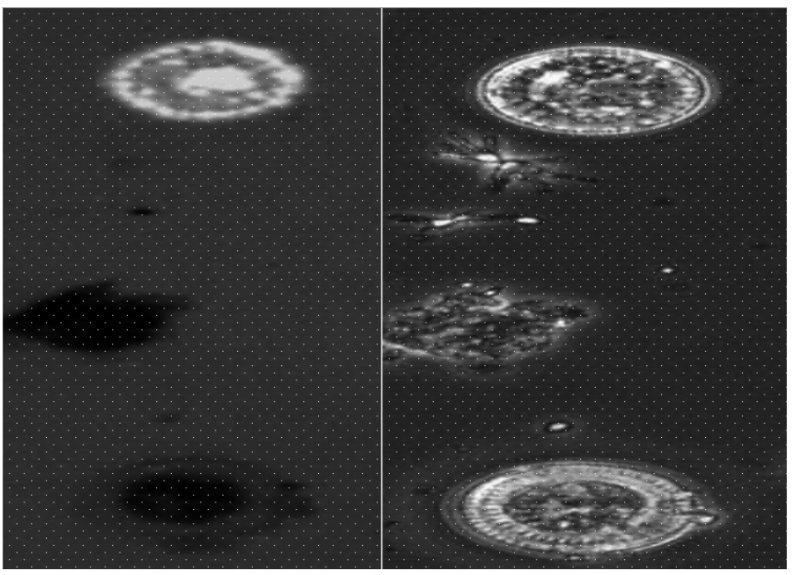

Figure 2 - Alive and dead microorganisms, the same sample detected by flow cytometer right after the ballast water treatment and hours later [11]

\subsubsection{CytoBuoy}

CytoBuoy instruments use silico-imaging as a basic data format: data-extensive but highly informative optical fingerprints obtained by fluid driven laser scanning of individual particles. Libraries of these fingerprints allow for automatic classification and enumeration of groups and species from large data sets as well as for online warning for the target of harmful algae species [11].

It is possible to connect and read detection results on line. Figure 3 shows the size of a flow cytometer and the size of a buoy. The photo was taken while the researcher and author of this paper visited the CytoBuoy institute in Woerden, Holland.

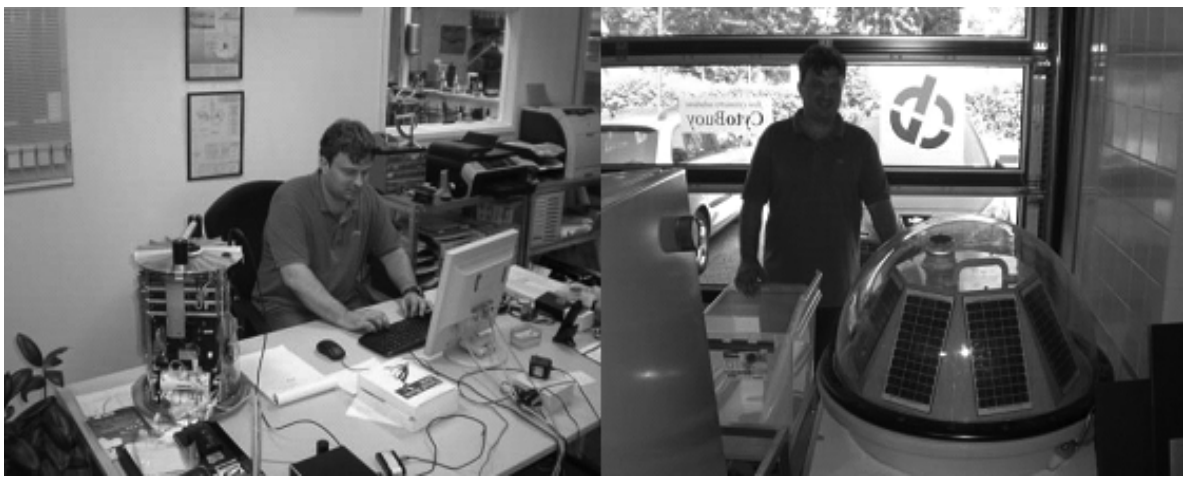

Figure 3 - The buoy and flow cytometer (at the desk, connected to the computer) in the buoy (right side picture) 
In order to be able to take the instrument and put it into/under the water, the flow cytometer was completely redesigned to get much smaller and modular. The basic instrument which is a scanning flow cytometer can hold 2 lasers and up to 10 optical detectors in a $30 \times 45 \mathrm{~cm}$ cylinder of only $15 \mathrm{~kg}$. The instrument is fully computer programmable with the possibility to read out the data files over internet if needed. The same instrument can be placed in a moored buoy or a high pressure submersible housing which makes field measurements possible on real live samples (without filtering, fixatives, transportation or waiting), anywhere, anytime [11]. Results of the flow cytometer operation in the buoy are very similar to the quality of the results obtained from the cytometer when used in a laboratory. This product has been in use for phytoplankton researches, but it is developed enough to implicate the use of flow cytometer for more purposes, such as the ballast water quality detection. A buoy of that function and capacity is shown in the following Figure 4. The long blue cable was in use for communication between the computer and the buoy itself.

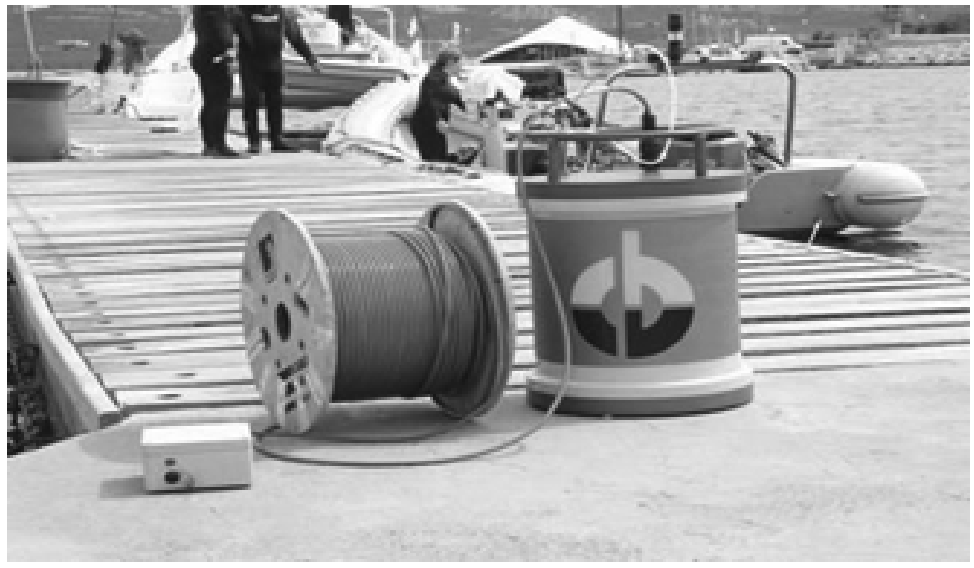

Figure 4 - Buoy equipped for automatic flow cytometry phytoplankton researches $[17][18]$

Applications of the cytobuoy are not only in the screening of phytoplankton. In biology and biological researches, it is also in use for detection of rare species, population dynamics research, and assessment of biodiversity, bio-indicators, harmful algal blooms and micro zooplankton. It is in use for analyses of drinking and bathing water, resource water and lake restoration. One of the possibilities was researched for chemical elements detection in cleaning residues discharged from chemical tanker ships in coastal areas. A solution has been brought up proposing the use of flow cytometer as a detection tool and of GPS data as the means to carry out the "pump and valves shut-off " function [10]. 


\section{Possibility of use of flow cytometry in the treated ballast water quality detection}

The analyzed applications implicate the possibility for the in-line flow cytometer to be used on board ship, which is the idea presented in this paper. A sophisticated instrument like the flow cytometer could be fixed onto the ballast water pipeline system at the location that is available for detection of all ballast water tanks on board ship. The best location is in the engine room by the ballast pump recirculation pipeline [9]. The following Figure 5 shows the possible arrangement.

The maintenance of the flow cytometer requires calibration after each use for the ballast water detection and that operation could be done by a properly trained crew member on board through a computer program comparing the colors and equalizing them according to calibrating software. The protocol to guide the flow cytometer for this purpose should be done as well. The data could be filed and processed as per the agreed requirements [4].

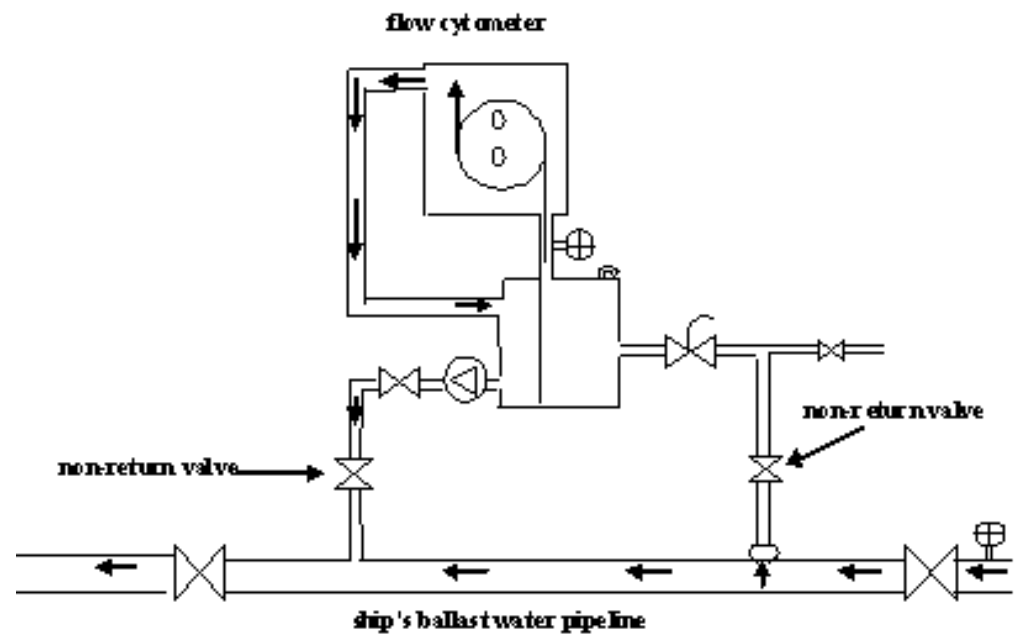

Figure 5 - Flow cytometer detection scheme of ballast water system [4]

The following calculation deals with an example of a ship of $100000 \mathrm{dwt}$ discharging $33000 \mathrm{~m}^{3}$ of ballast water in a port of call for cargo operations. A flow cytometer could automatically take and process 8 samples of $1 \mathrm{ml}$ (required number of samples taken during the tests for systems approval in the institutes) from a ship's ballast tank of $2000 \mathrm{~m}^{3}$ capacity. It is necessary to take 9 samples from each of the random chosen $15 \mathrm{~m}^{3}$ for sampling (as per test requirements of MEPC 53/24, add. 1, annex 3, chapter 2.2.2. [21]). In this accordance, a tank of $2000 \mathrm{~m}^{3}$ capacity requires 8 samples of 1 
$\mathrm{ml}$. It is possible to calculate mathematical expectancy of whether a flow cytometer would detect the Escherichia Coli bacteria (neutralization required by the Ballast Water Convention) in automatically taken samples in the cytometer sampling unit if the treatment was not successful enough:

$$
\mathrm{X}=(\mathrm{Xn}: \mathrm{n} \geq 1)
$$

Markov estimation state:

$$
\begin{gathered}
\mathrm{S}=\left\{0,1,2, \ldots ., \mathrm{N}-1, \mathrm{~N}^{\prime}, \mathrm{N}^{\prime}\right. \\
\mathrm{Xn}=\mathrm{i}
\end{gathered}
$$

if, at the sampling moment, the $\mathrm{i}$ bacteria do exist and the $\mathrm{N}$ situation has been shown in two options, depending on the experience factor of the latest sample detection, whether the bacteria were found/ detected or not (N', N"),

$(\mathrm{q}=1-\mathrm{p})$ is a Markov transition matrix in this chain and the implication is:

$$
\pi=\frac{1}{N+q}
$$

The possibility of finding remaining microorganisms after the ballast water has been treated by automatic ballast water management system on board can be calculated as follows:

$$
\frac{1}{N} \sum_{n=1}^{N} 1\left(X n=N^{\prime \prime}\right)=\pi N^{\prime \prime}=\frac{p q}{N+q} \quad \text { g.s. }=0.8165
$$

The result is a very high percentage of $82 \%$ even after a very good ballast water treatment method applied.

If the failures for this kind of system were calculated, the result would be:

$$
m=\int_{0}^{\infty} R(t) d t=\int_{0}^{\infty} e^{-\lambda t} \mid d t=\frac{1}{\lambda}
$$

where:

$\lambda$ malfunction index

$\mathrm{R}$ reliability

The final reliability $R(t)$ of this detection system is:

$$
R(t)=e^{-\frac{t}{m}}=0.951
$$

The high percentage is the result that gives trustful information for starting a new serious research of the use of a flow cytometer as a trustful and reliable tool when resolving the problem of having a representative sample of treated ballast water on any 
ship. This way of detection implicates a scientific contribution to the automatic water quality detection in any contaminated areas dangerous for humans.

\section{Conclusion}

This paper reviews the monitoring of ballast water treatment systems. A ballast water inspector could inspect ballast water if he found any indication of non compliance with BWMC 2004 requirements. The fast and quantitative diagnostic capabilities of the flow cytometers may be of a great help for the fast screening of ballast water by generating countings and accurate size spectra for sediment particles, phytoplankton and other groups of particles. This can be used to monitor the efficiency of organism targeted treatments, or can even serve as a feedback mechanism to actively control treatment performance [11]. Mathematical calculation has brought up final reliability of the suggested detection system and that was 0.951 . The result of the calculated possibility of finding any remaining microorganisms after the ballast water has been treated by an automatic ballast water management system on board was 0.8165 . That result represents a very high percentage of $81.7 \%$. This means that this detection system would detect bacteria and microorganisms required by the D-2 regulation of the Ballast Water Management Convention. The flow cytometer detection system on board ship should be located in the engine room by the ballast pump and should be installed on a separate pipeline connected to the main ballast water pipeline system. Using of flow cytometer in the research buoy implicates the possibility of use of a flow cytometer on ships for the quality of the ballast water detection.

This possibility of using flow cytometer for the purpose described requires further research on board ship and could be improved by a remotely operated ballast pump, ballast tank valves and a flow cytometer [8][6]. 


\section{References}

1. Albert, R.J., Lishman, J.M., Saxena, J.R.: "Ballast Water Regulations and the move toward concentration-based numeric discharge limits”, Ecol Appl 23(2), pp.289-300, 2013.

2. Aliotta, J., Rogerson, A., Campbell, C.B., Yonge, M.: "Ballast Water Treatment by Electro-Ionization”, 1st International Ballast Water Treatment R\&D Symposium, Proceedings, pp. 61-69, 2001. http://globallast.imo.org/wp-content/uploads/2014/11/Mono5.pdf. (Accessed: 10 January 2016)

3. Asai, R., Otani, K., Nakamura, C., Ikebukuro, K., Arikawa, Y., Miyake, Y., Karube, I.: "PCRBased Ribosomal DNA Detection Technique for Microalga (Heterosigma carterae) Causing Red Tide and Its Application to a Biosensor Using Labeled Probe", Marine Biotechnology, Vol. 5, Issue 5, pp. 417-423, 2003, available on internet web site: http://www.springerlink.com/ content $/ 5$ wr78nck $7 \mathrm{~m} 01$ vheu/ (Accessed: 5 February, 2016).

4. Bakalar, G.: "Automatic control system for ship ballast water treatment by using flow cytometry and satellite communications technologies", PhD thesis, 170 pp., Rijeka University, Croatia, 2013.

5. Bakalar, G.: "Review of interdisciplinary devices for detecting the quality of ship ballast water", SpringerPlus 1(3):468. doi: 10.1186/2193-1801-3-468, 2014.

6. Bakalar, G.: "A thesis on a remotely controlled BWTS", The Ballast Water Times II, Journal of Institute NIOZ, project NSBWO (North Sea Ballast Water Opportunity) project financed by EU, EK, 2012(2), pp. 3, 2012.

7. Bakalar, G.: "Efforts to develop a ballast water detecting device," Global IMO R\&D Forum on Compliance Monitoring and Enforcement, Proceedings, Istanbul, Turkey, pp. 117-126, 2011. http://globallast.imo.org/wp-content/uploads/2015/01/RD_Turkey_2011.pdf(Accessed: 7 January 2016.).

8. Bakalar, G.Tomas, V.: "Possibility of using satellite communication technologies for remote maintenance in marine industry," 5th GNSS Vulnerabilities and Solutions Conference, 2011.

9. Bakalar, G., Tomas, V., Sesar, Z.: "Remote Monitoring of Ballast Water Treatment System Quality by Using Flow Cytometry and Satellite Communication Technologies", 54th International Symposium ELMAR 2012, Proceedings, pp. 290-295, 2012.

10. Bakalar, G., Tomas, V., Buksa, A.: "Monitoring of chemical pollution from the ships in coastal area", REACT Conference: International Conference on Climate Friendly Transport: Shaping Climate Friendly Transport in Europe, Key Findings \& Future Directions", Belgrade, Serbia, 2011. http://bib.irb.hr/prikazirad?lang=en\&rad=520608 (Accessed: 15 January, 2016).

11. Cangelosi, A.: "Great ships initiative sampling systems for land - and ship - based ballast water treatment system performance testing", Proceedings of Global R\&D Forum on Ballast Water Management, October 26-28, Istanbul, Turkey, pp. 83-109, 2011. http://globallast.imo.org/2013/ RD_Turkey_2011.pdf (Accessed: 6 February, 2016).

12. Gregg, M., Rigby, G., Hallegraeff, G.M.: "Review of two decades of progress in the development of management options for reducing or eradicating phytoplankton, zooplankton and bacteria in ship's ballast water", Aquat Inv 4(3), pp. 521-565, 2009.

13. National Institute of General Medical Sciences, Washington DC, USA, http://publications.nigms. nih.gov/thenewgenetics/chapter1.html\#c1 (Accessed: 28 January, 2016)

14. Nunez, R.: "Introduction to the field of Cytometry and its importance in biomedicine", Curr. Issues Mol. Biol. 3(2): pp. 37-38, 2001, Available on internet web site: http://www.horizonpress.com/ $\mathrm{cimb} / \mathrm{v} / \mathrm{v} 3 / \mathrm{v} 3 n 203 . p d f$. (Accessed: 28 January, 2016)

15. Van Der Star, I., Liebig, V., Stehouwer, P. P.: "The importance of organisms smaller than $10 \mu \mathrm{m}$ ", Proceedings of Global R\&D Forum on Ballast Water Management, October 26-28, Istanbul, Turkey, pp. 41-50, 2011. http://globallast.imo.org/2013/RD_Turkey_2011.pdf (Accessed: 6 February, 2016).

16. http://en.wikipedia.org/wiki/Flow_cytometry (Accessed: 15 January, 2016).

17. www.cytobuoy.com (Accessed: $5 \overline{\text { February, 2016). }}$

18. http://www.cytobuoy.com/applications/aquaticscience.php (Accessed: 15 January, 2016)

19. http://www.cytobuoy.com/products/cytobuoy_flow_cytometer.php (Accessed: 15 January, 2016)

20. http://globallast.imo.org/index.asp?page $=$ mepc.htm\&menu=true(Accessed: 28 January, 2016)

21. http://www.uscg.mil/imo/mepc/docs/mepc53-report-add-1.pdf (Accessed: 17 February 2016) 


\section{Mogućnost korištenja protočne citometrije u detekciji kvalitete tretirane balastne vode}

\section{Sažetak}

U ovom članku se analizira potreba za nadzorom brodske balastne vode nakon što je tretirana sustavom za obradu brodskog balasta. Efikasnost takvih sustava se pokazala kao veći problem jer ne postoji sustav praćenja rada takvih postrojenja. Cilj koji se želio postići u ovom članku je bio naglasiti potrebu za nadzorom rezultata rada takvih sustava te predložiti rješenje. Analizirane su tehnologija protočne citometrije i uporaba protočnih citometara u detekciji sastojaka vode. Rezultati rada protočnog citometra su potvrđeni i matematički. Mogućnost pronalaženja preostalih mikroorganizama protočnim citometrom u tretiranoj balastnoj vodi je izračunata i rezultat je vrlo veliki postotak od $82 \%$. Protočni citometar je predložen kao rješenje. Rezultati analiza u ovom članku pomažu u razumijevanju važnosti nadgledanja rezultata rada sustava obrade balastnih voda jer je to, između ostaloga, u interesu očuvanja okoliša.

Ključne riječi: balast, metode pročišćavanja, detekcija, protočna citometrija 
